\title{
ANALISIS KESALAHAN PENGGUNAAN BAHASA INDONESIA DALAM KATA PENGANTAR SKRIPSI MAHASISWA PBSI FKIP UNSYIAH
}

\author{
oleh \\ Novira Sabrina \\ Fakultas Bahasa dan Sastra Indonesia \\ Universitas Syiah Kuala
}

\begin{abstract}
ABSTRAK
Penelitian yang berjudul "Analisis Kesalahan Penggunaan Bahasa Indonesia dalam Kata Pengantar Skripsi Mahasiswa PBSI FKIP Unsyiah" ini bertujuan mendeskripsikan kesalahan penggunaan bahasa Indonesia dalam kata pengantar skripsi mahasiswa PBSI FKIP Unsyiah. Sumber data penelitian ini adalah skripsi mahasiswa PBSI FKIP Unsyiah tahun 2010. Penelitian ini menggunakan metode deskriptif kualitatif. Pengumpulan data dilakukan dengan menggunakan metode dokumentasi. Data yang telah terkumpul diolah secara kualitatif. Hasil penelitian menunjukkan bahwa masih terdapat kesalahan penggunaan bahasa Indonesia dalam kata pengantar skripsi mahasiswa PBSI FKIP Unsyiah tahun 2010, yaitu kesalahan EYD 50\%, kesalahan diksi 21\%, kesalahan kalimat 15\%, kesalahan paragraf 5\%, dan kesalahan sistematika penulisan kata pengantar $11 \%$. Berdasarkan hasil penelitian tersebut, kesalahan penggunaan bahasa Indonesia yang dominan muncul adalah aspek kesalahan ejaan atau EYD.
\end{abstract}

\section{PENDAHULUAN}

Secara umum pembelajaran bahasa Indonesia di perguruan tinggi bertujuan supaya setiap mahasiswa dapat terampil berbahasa Indonesia. Terampil berbahasa yang dimaksudkan adalah terampil menyimak, berbicara, membaca, dan menulis (terampil menggunakan bahasa Indonesia yang baik dan benar), baik secara lisan maupun tulisan. Sebagaimana yang dikatakan oleh Tarigan (1994:1) bahwa keterampilan berbahasa mempunyai empat komponen, yaitu (a) keterampilan menyimak (listening skills), (b) keterampilan berbicara (speaking skills), (c) keterampilan membaca (reading skills), dan (d) keterampilan menulis (writing skills). 
Kenyataan membuktikan bahwa kompetensi kebahasaan (bahasa Indonesia) yang dimiliki oleh mahasiswa masih relatif rendah, terutama pada keterampilan menulis mahasiswa. Hal ini dapat dilihat dari banyaknya kesalahan penggunaan bahasa Indonesia yang digunakan oleh mahasiswa dalam karya ilmiah yang mereka hasilkan. Padahal, pembelajaran bahasa Indonesia sudah diberikan dan dipelajari sejak sekolah dasar sampai dengan perguruan tinggi. Fenomena ini juga terjadi pada mahasiswa Pendidikan Bahasa dan Sastra Indonesia (PBSI), Fakultas Keguruan dan Ilmu Pendidikan (FKIP), Universitas Syiah Kuala (USK). Mereka seharusnya lebih memperhatikan penggunaan bahasa Indonesia yang baik dan benar dalam penulisan skripsi yang mereka hasilkan karena ide atau gagasan yang disampaikan secara tertulis akan dibaca oleh siapa saja.

\section{PEMBAHASAN}

Sebagaimana yang tercantum dalam buku Pedoman Penulisan Skripsi FKIP Unsyiah (2007:24) bahwa penulisan skripsi harus mengikuti kaidah-kaidah bahasa. Kaidah-kaidah tersebut mencakup ejaan, pilihan kata (diksi), kalimat, dan paragraf. Ejaan yang digunakan harus mengikuti kaidah ejaan bahasa Indonesia yang disempurnakan. Pilihan kata (diksi) harus menggunakan kata yang baku atau lazim, kata yang hemat, dan kata yang cermat. Kalimat-kalimat yang digunakan adalah kalimat yang efektif, sedangkan paragraf-paragraf yang disusun harus logis dan sistematis. Dengan kata lain, bahasa yang digunakan dalam penulisan skripsi adalah bahasa tulis baku yang tepat, jelas, lugas, dan komunikatif supaya pembaca dapat memahami isi atau informasi yang disampaikan penulis dengan mudah, terutama dalam penulisan kata pengantar skripsi.

Menurut Kamus Besar Bahasa Indonesia atau KBBI (2008:633), kata pengantar adalah kata pendahuluan. Dalam kaitan ini, Azwardi (2009:119-120) mengemukakan beberapa hal sebagai berikut.

"Dalam kata pengantar sekurang-kurangnya berisi hal-hal berikut: (1) penjelasan mengenai tugas pembuatan karya ilmiah tersebut, (2) penjelasan mengenai pelaksanaan pembuatan karya ilmiah, (3) informasi tentang bimbingan atau arahan dan bantuan yang diperoleh sehubungan dengan pembuatan karya ilmiah, (4) ucapan terima kasih kepada pihak-pihak yang 
membantu dan memungkinkan terwujudnya karya ilmiah, dan (5) penyebutan tempat (kota), tanggal, bulan, tahun pembuatan karya ilmiah, dan nama penulis".

Selain itu, tulisan kata pengantar ditulis dengan huruf kapital, simetris di batas atas bidang pengetikan dan tanpa diakhiri tanda titik. Teks kata pengantar diketik dengan spasi ganda (dua spasi). Panjang teks tidak lebih dari dua halaman kertas ukuran kuarto. Pada bagian akhir teks (di pojok kanan bawah) dicantumkan kata penulis tanpa menyebut nama terang (FKIP Unsyiah, 2007:10).

Berikut ini adalah kasus kesalahan penggunaan bahasa Indonesia dalam kata pengantar skripsi mahasiswa PBSI FKIP Unsyiah tahun 2010.

(1) Kesalahan pemakaian huruf tebal pada tulisan kata pengantar sebagai tajuk, yaitu KATA PENGANTAR. Berdasarkan kaidah EYD, huruf tebal dalam cetakan dipakai untuk menuliskan judul buku, bab, bagian bab, daftar isi, daftar tabel, daftar lambang, daftar pustaka, indeks, dan lampiran. Dengan demikian, alternatif pembetulannya adalah KATA PENGANTAR.

(2) Kesalahan pemakaian huruf miring pada judul skripsi dan tidak hadirnya unsur predikat dalam kalimat berikut.

Alhamdulillah, puji syukur_kepada Allah swt. yang telah memberikan rahmat dan hidayah-Nya kepada penulis sehingga skripsi yang berjudul "Analisis Kesalahan Penggunaan Ejaan pada Skripsi Mahasiswa Nonbahasa Indonesia FKIP Unsyiah" dapat diselesaikan dengan baik.

Berdasarkan kaidah EYD, judul skripsi, tesis, atau disertasi yang belum diterbitkan dan dirujuk dalam tulisan tidak ditulis dengan huruf miring, tetapi diapit dengan tanda petik. Selain itu, di antara kata ... puji syukur dan kepada Alah swt. .... sebaiknya dibubuhi kata penulis ucapkan sebagai unsur predikat supaya unsur-unsur kalimat di atas jelas dan lengkap. Dengan demikian, alternatif pembetulannya adalah sebagai berikut.

(2a) Alhamdulillah, puji syukur penulis ucapkan ke hadirat Allah swt. yang telah memberikan rahmat dan hidayah-Nya kepada penulis sehingga skripsi yang berjudul "Analisis Kesalahan Penggunaan Ejaan pada 
Skripsi Mahasiswa Nonbahasa Indonesia FKIP Unsyiah” dapat diselesaikan dengan baik.

(3) Kesalahan ejaan, diksi, kalimat, dan sistematika penulisan kata pengantar dalam paragraf berikut.

Atas bantuan tersebut_penulis mengungkapkan terima kasih terutama kepada Dekan Fakultas Keguruan dan Ilmu Pendidikan yang telah memberi kesempatan kepada penulis sehingga dapat menyelesaikan studi di FKIP Unsyiah; kedua,_kepada Drs. Teuku Alamsyah, M.Pd. selaku Ketua Program Studi Pendidikan Bahasa dan Sastra Indonesia; ketiga,_kepada Dr. Ramli, M.Pd. sebagai pembimbing utama dan Muhammad Idham, S.Pd., M.Ed. sebagai pembimbing kedua yang telah sudi memberi bimbingan dan arahan kepada penulis hingga penyusunan skripsi ini rampung; keempat,_kepada para

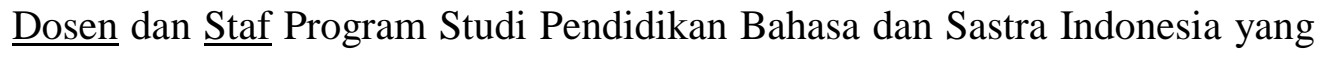
turut serta membantu kelancaran penulis skripsi ini; kelima,_kepada guru-guru yang telah sudi memberi bekal ilmu kepada penulis sehingga penulis dapat melanjutkan ke perguruan tinggi; keenam,_kepada Ibunda dan Ayahanda tercinta beserta seluruh keluaga besar yang telah memberi dorongan, doa, materi, dan semangat; dan ketujuh,_kepada teman-teman seperjuangan yang selalu ada menemani penulis saat suka dan duka.

Kesalahan paragraf di atas adalah sebagai berikut. Pertama, kesalahan ejaan dalam paragraf di atas adalah (1) tidak menggunakan tanda koma (,) di antara keterangan dan subjek, yaitu di antara kata atas bantuan tersebut dan kata penulis. Berdasarkan kaidah EYD, tanda koma (,) digunakan untuk menghindari salah baca di belakang keterangan yang terdapat pada awal kalimat; (2) kesalahan pemakaian huruf kapital pada huruf pertama kata Ibunda dan Ayahanda. Berdasarkan kaidah EYD, huruf kapital dipakai sebagai huruf pertama kata penunjuk hubungan kekerabatan, seperti bapak, ibu, saudara, kakak, adik, dan paman, yang digunakan dalam penyapaan atau pengacuan; (3) kesalahan pemakaian huruf kapital pada huruf pertama kata Dosen dan Staf. Berdasarkan kaidah EYD, huruf kapital dipakai sebagai huruf pertama unsur nama jabatan yang diikuti nama orang, nama instansi, atau nama tempat yang 
digunakan sebagai pengganti nama orang tertentu. Kedua, kesalahan diksi dalam paragraf di atas adalah kata-kata yang dipilih tidak mengungkapkan pengertian yang tepat, yaitu pada kata dorongan dan terutama. Kata yang tepat untuk kata tersebut adalah kata motivasi dan pertama. Ketiga, kesalahan kalimat dalam paragraf di atas adalah tidak hadirnya unsur subjek dan predikat pada kalimat kedua, kepada Drs. Teuku Alamsyah, M.Pd. selaku Ketua Program Studi Pendidikan Bahasa dan Sastra Indonesia; .... Supaya kalimat tersebut jelas dan lengkap, sebaiknya dibubuhi kata penulis sebagai unsur subjek dan kata mengucapkan sebagai unsur predikat, dan kata terima kasih sebagai unsur objek. Kempat, kesalahan sistematika penulisan kata pengantar dalam paragraf di atas adalah ucapan terima kasih penulis yang pertama tidak ditujukan untuk dosen pembimbing. Berdasarkan buku Pedoman Penulisan Skripsi FKIP Unsyiah, teks kata pengantar berisi ucapan terima kasih penulis kepada orang-orang (terutama pembimbing), lembaga, organisasi, dan pihak-pihak lain yang telah membantu penulis dalam penyelesaian skripsi. Dengan demikian, alternatif pembetulan paragraf di atas adalah sebagai berikut.

(3a) Atas bantuan tersebut, pertama, penulis mengucapkan terima kasih kepada Dr. Ramli, M.Pd. sebagai pembimbing pertama dan Muhammad Idham, S.Pd., M.Ed. sebagai pembimbing kedua yang telah sudi memberi bimbingan dan arahan kepada penulis hingga penyusunan skripsi ini rampung; kedua, penulis mengucapkan terima kasih kepada Drs. Teuku Alamsyah, M.Pd. selaku Ketua Program Studi Pendidikan Bahasa dan Sastra Indonesia; ketiga, penulis mengucapkan terima kasih kepada Dekan Fakultas Keguruan dan Ilmu Pendidikan yang telah memberi kesempatan kepada penulis sehingga dapat menyelesaikan studi pada FKIP Unsyiah; keempat, penulis mengucapkan terima kasih kepada para dosen dan staf Program Studi Pendidikan Bahasa dan Sastra Indonesia yang ikut serta membantu kelancaran penulis skripsi ini; kelima, penulis mengucapkan terima kasih kepada guru-guru yang telah sudi memberi bekal ilmu kepada penulis sehingga penulis dapat melanjutkan ke perguruan tinggi; keenam, penulis mengucapkan terima kasih kepada ibunda dan ayahanda tercinta beserta seluruh keluarga besar yang telah 
memberi motivasi, doa, materi, dan semangat; ketujuh, penulis mengucapkan terima kasih kepada teman-teman seperjuangan yang selalu ada menemani penulis saat suka dan duka.

Berdasarkan hasil pengamatan data di atas, alasan penulis memilih topik ini adalah sebagai berikut.Pertama, pada umumnya ketika menyusun kata pengantar skripsi, mahasiswa PBSI FKIP Unsyiah hanya terfokus untuk menghasilkan kalimat sebanyak mungkin sehingga banyak paragraf yang terbentuk tanpa memperhatikan penerapan kaidah-kaidah bahasa yang baik dan benar dalam tulisannya. Kedua, mahasiswa PBSI FKIP Unsyiah sudah memprogramkan mata kuliah Keterampilan Menulis dan juga sudah memprogramkan mata kuliah Ejaan Bahasa Indonesia. Selama memprogramkan kedua mata kuliah tersebut, tentunya mahasiswa PBSI FKIP Unsyiah sudah mempelajari dan mengetahui syarat-syarat penulisan karya tulis yang baik dan benar serta sudah menguasai pedoman umum Ejaan Yang Disempurnakan (EYD). Ketiga, penelitian mengenai topik ini sudah pernah dilakukan, antara lain (1) Erni Ningsih (2010) mengkaji analisis kesalahan penggunaan ejaan pada skripsi mahasiswa nonbahasa Indonesia FKIP Unsyiah dan (2) Muhammad Nur (2010) mengkaji analisis pemakaian bahasa Indonesia ragam tulis dalam skripsi mahasiswa IAIN Ar-Raniry asal Malaysia.

Penelitian ini bertujuan mendeskripsikan kesalahan penggunaan bahasa Indonesia dalam kata pengantar skripsi mahasiswa PBSI FKIP Unsyiah. Penelitian ini diharapkan bermanfaat bagi peneliti, mahasiswa, dan masyarakat umum, baik secara teoretis maupun praktis. Secara teoretis, penelitian ini diharapkan dapat mendukung penggunaan bahasa Indonesia yang baik dan benar di dalam sebuah tulisan (karya tulis). Secara praktis, penelitian ini dapat dijadikan sebagai acuan dalam penulisan karya tulis yang sesuai dengan kaidah bahasa Indonesia yang baik dan benar sehingga membantu pembaca dalam memahami informasi yang disampaikan secara tertulis. 


\section{METODE PENELITIAN}

Sumber data penelitian ini adalah skripsi mahasiswa PBSI FKIP Unsyiah. Keseluruhan sumber data berjumlah 20 skripsi. Skripsi yang dijadikan data penelitian ini adalah kata pengantar skripsi mahasiswa PBSI FKIP Unsyiah tahun 2010. Namun, data yang akan dianalisis berjumlah empat teks kata pengantar. Penentuan jumlah data tersebut berdasarkan pendapat Gay. Gay (dalam Umar 2005:79) menyatakan bahwa jika desain penelitian yang digunakan adalah metode deskriptif, ukuran minimum sampel yang dapat diterima minimal $10 \%$ populasi. Untuk populasi yang relatif kecil minimal $20 \%$ populasi. Berdasarkan pernyataan tersebut, mengingat keseluruhan sumber data relatif kecil maka data penelitian yang diambil adalah 20\% dari keseluruhan sumber data. Oleh karena itu, data yang akan dianalisis berjumlah empat teks kata pengantar.

Pengambilan data penelitian ini dilakukan secara acak (random) melalui cara undian. Cara yang dilakukan adalah menuliskan nomor pada seluruh teks kata pengantar skripsi mahasiswa PBSI FKIP Unsyiah tahun 2010, kemudian secara acak peneliti memilih empat teks kata pengantar sehingga nomor-nomor yang terpilih dan tertera di teks tersebut merupakan nomor data penelitiannya.

Metode yang digunakan dalam penelitian ini adalah metode deskriptif kualitatif. Metode ini disebut juga metode penelitian kualitatif. Metode penelitian kualitatif adalah prosedur penelitian yang menghasilkan data deskriptif berupa katakata tertulis atau lisan dari orang-orang atau perilaku yang dapat diamati (Bogdan dan Taylor, dalam Basrowi dan Suwandi 2008:21). Penggunaan metode ini sesuai dengan maksud penulis, yakni untuk mendeskripsikan dan menganalisis data kesalahan penggunaan bahasa Indonesia dalam kata pengantar skripsi mahasiswa PBSI FKIP Unsyiah tahun 2010 secara jelas dan sistematis. Pendeskripsian dan penganalisisan data tersebut meliputi lima aspek kesalahan, yaitu (1) EYD, (2) pilihan kata atau diksi, (3) kalimat, dan (4) paragraf, dan (5) sistematika penulisan kata pengantar. Langkah kerja penelitian ini adalah mengumpulkan data, mengklasifikasikan data, menganalisis data, dan menginterpretasikan data sehingga dapat ditarik suatu simpulan penelitian. 
Teknik pengumpulan data dalam penelitian ini menggunakan metode dokumentasi. Metode dokumentasi adalah kegiatan mengumpulkan data dengan mempelajari dokumen tertulis yang diperlukan (Parwanto, 2006:113). Dalam melaksanakan metode dokumentasi, peneliti menyelidiki benda-benda tertulis seperti buku, majalah, dokumen, peraturan-peraturan, notulen rapat, catatan harian, dan sebagainya (Arikunto, 2006:158). Metode ini dianggap lebih tepat mengingat data yang dikumpulkan adalah teks kata pengantar skripsi mahasiswa PBSI FKIP Unsyiah tahun 2010.

Data yang telah terkumpul diolah secara kualitatif. Artinya, data dianalisis dan dideskripsikan sesuai rumusan masalah yang telah ditetapkan. Sebagaimana yang dikatakan oleh Tarigan (1995:70) bahwa analisis kesalahan (anakes) adalah suatu prosedur kerja. Prosedur kerja analisis kesalahan yaitu (1) mengumpulkan sampel kesalahan, (2) mengindentifikasi kesalahan, (3) menjelaskan kesalahan, (4) mengklasifikasi kesalahan, dan (5) mengevaluasi kesalahan (Ellis, dalam Tarigan 1995:70).

Peneliti menganalisis data yang terkumpul dengan prosedur analisis data yang disesuaikan dengan tujuan yang ingin dicapai. Untuk memperoleh frekuensi relatif (angka persenan) digunakan rumus yang dikemukakan oleh Sudijono (2009:43), yaitu sebagai berikut.

$$
\mathrm{p}=\frac{\mathrm{f}}{\mathrm{N}} \times 100 \%
$$

$\mathrm{p}=$ persentase yang dicari

$\mathrm{f}=$ frekuensi banyaknya kesalahan EYD, diksi, kalimat, paragraf, dan sistematika penulisan kata pengantar

$\mathrm{N}=$ Number of Cases (jumlah keseluruhan kesalahan penggunaan bahasa Indonesia)

\section{HASIL PENELITIAN DAN PEMBAHASAN}

Data penelitian ini adalah kata pengantar skripsi mahasiswa PBSI FKIP Unsyiah tahun 2010. Data yang terkumpul berjumlah 20 teks kata pengantar. Namun, 
data yang akan dianalisis berjumlah empat teks. Keempat teks tersebut dapat dilihat pada bagian lampiran. Data kesalahan penggunaan bahasa Indonesia dalam keempat teks tersebut meliputi lima aspek kesalahan. Kelima aspek kesalahan itu adalah (1) kesalahan EYD, (2) kesalahan diksi, (3) kesalahan kalimat, (4) kesalahan paragraf, dan (5) kesalahan sistematika penulisan kata pengantar.

Secara umum kesalahan sistematika penulisan kata pengantar dari keempat teks pada bagian lampiran adalah sebagai berikut:

1) tajuk kata pengantar menggunakan huruf Algerian 14,5 pt. Berdasarkan buku Pedoman Penulisan Skripsi FKIP Unsyiah, pengetikan skripsi harus menggunakan huruf Times New Roman 12 pt atau Garamond 13 pt. Dengan demikian, huruf yang digunakan tajuk kata pengantar harus sesuai dengan pengetikan skripsi karena kata pengantar merupakan bagian daripada skripsi;

2) tajuk kata pengantar dicetak menggunakan huruf tebal. Berdasarkan kaidah EYD, huruf tebal dalam cetakan dipakai untuk menuliskan judul buku, bab, bagian bab, daftar isi, daftar tabel, daftar lambang, daftar pustaka, indeks, dan lampiran;

3) awal paragraf salah satu kata pengantar tidak dimulai 1,2 $\mathrm{cm}$ dari tepi kiri bidang pengetikan;

4) salah satu isi kata pengantar ada yang tidak diketik dengan jarak dua spaci. Berdasarkan buku Pedoman Penulisan Skripsi FKIP Unsyiah, skripsi diketik dengan jarak dua spasi;

5) ucapan terima kasih penulis yang pertama tidak ditujukan kepada dosen pembimbing. Berdasarkan buku Pedoman Penulisan Skripsi FKIP Unsyiah, teks kata pengantar berisi ucapan terima kasih penulis kepada orang-orang (terutama pembimbing), lembaga, organisasi, dan pihak-pihak lain yang telah membantu penulis dalam penyelesaian skripsi;

6) cara penulisan atau tata letak nama kota (tempat), tanggal, bulan (ditulis lengkap dengan huruf, bukan angka), dan tahun penyusunan karya ilmiah tidak sesuai dengan sistematika penulisan kata pengantar. Ada beberapa pendapat mengenai cara penulisan atau tata letak tersebut, yaitu sebagai berikut. Pertama, berdasarkan buku Pedoman Penulisan Skripsi FKIP Unsyiah (2007:10), pada 
bagian akhir teks (di pojok kanan bawah) dicantumkan kata penulis tanpa menyebut nama terang. Kedua, berdasarkan modul Menulis Ilmiah (Azwardi, 2009:120), nama kota (tempat), tanggal, bulan (ditulis lengkap dengan huruf, bukan angka), dan tahun penyusunan karya ilmiah ditempatkan di sebelah kanan bawah dengan jarak empat spasi dari baris terakhir teks, sedangkan nama penulis ditempatkan di bawah nama kota itu dengan jarak dua spasi. Ketiga, berdasarkan buku Bahasa Indonesia Mata Kuliah Pengembangan Kepribadian di Perguruan Tinggi (Widjono, 2007:274), nama kota, tanggal, bulan, tahun, dan nama penulis dicantumkan secara lengkap tanpa dibubuhi tanda tangan;

7) nomor halaman kata pengantar ada yang tidak dicantumkan. Azwardi (2009:133) mengatakan bahwa nomor halaman kata pengantar dicetak dengan angka romawi kecil. Nomor halaman diletakkan di bagian bawah-tengah berjarak spasi 2 dari margin bawah.

Agar lebih jelas, berikut ini akan disajikan salah satu alternatif pembetulan dari keempat kata pengantar skripsi mahasiswa PBSI FKIP Unsyiah tahun 2010.

\section{KATA PENGANTAR}

Alhamdulillah, penulis mengucapkan puji syukur ke hadirat Allah swt. yang telah memberikan rahmat dan hidayah-Nya sehingga penulis dapat menyelesaikan skripsi yang berjudul "Analisis Penggunaan Bahasa Indonesia dalam Soal Buatan Guru SD Negeri 1 Rikit Gaib Kabupaten Gayo Lues” ini. Selanjutnya, selawat dan salam penulis sanjungkan ke junjungan Nabi Muhammad saw. beserta keluarga dan para sahabat beliau yang telah membawa umat manusia dari alam jahiliah ke alam islamiah.

Penulisan skripsi ini merupakan salah satu syarat untuk mendapatkan gelar sarjana pendidikan pada Fakultas Keguruan dan Ilmu Pendidikan, Universitas Syiah Kuala. Selama menyelesaikan skripsi ini, penulis banyak mengalami kendala, baik fisik maupun psikis. Namun, berkat usaha, doa, dan motivasi dari berbagai pihak skripsi ini dapat penulis selesaikan dengan baik.

Penulis telah banyak mendapatkan bimbingan dan bantuan dari berbagai pihak selama penulisan skripsi ini. Oleh karena itu, melalui kata pengantar ini, 
penulis mengungkapkan rasa terima kasih yang sebesar-besarnya kepada

1) Dr. Rajab Bahri, M.Pd. selaku pembimbing I dan Drs. Teuku Alamsyah, M.Pd. selaku pembimbing II yang telah meluangkan waktu dan pikiran untuk membimbing penulis hingga skripsi ini selesai,

2) Ketua serta Bapak dan Ibu staf pengajar Jurusan Pendidikan Bahasa Sastra Indonesia yang telah membekali penulis dengan berbagai disiplin ilmu pengetahuan,

3) Dekan Fakultas Keguruan Ilmu Pendidikan Universitas Syiah Kuala,

4) Kepala Dinas Pendidikan Pemuda dan Olahraga Kabupaten Gayo Lues, Kepala SD Negeri 1 Rikit Gaib, dan semua pihak yang telah membantu dalam proses penulisan skripsi ini,

5) kedua orang tua, kakak, dan abang penulis yang telah bersusah payah membantu, baik moral maupun material serta senantiasa mendoakan kebaikan untuk penulis, dan

6) sahabat-sahabat seperjuangan yang telah membantu dan memotivasi penulis sehingga penulisan skripsi ini selesai.

Penulis telah berupaya maksimal supaya penulisan skripsi ini sempurna. Namun, atas keterbatasan wawasan dan pengetahuan yang penulis miliki, penulis masih memerlukan segala perbaikan dari berbagai pihak. Oleh karena itu, penulis sangat mengharapkan kritik dan saran yang bersifat membangun demi kesempurnaan skripsi ini pada masa yang akan datang.

Darussalam, 10 Februari 2010

Penulis

i

Berdasarkan analisis yang telah dilakukan, keseluruhan data kesalahan yang diperoleh berjumlah 141 kesalahan. Kesalahan tersebut meliputi (a) kesalahan EYD sebanyak 71 kesalahan, (b) kesalahan diksi sebanyak 30 kesalahan, (c) kesalahan kalimat sebanyak 21 kesalahan, (d) kesalahan paragraf sebanyak 7 kesalahan, dan (e) 
kesalahan sistematika penulisan kata pengantar sebanyak 15 kesalahan. Untuk lebih jelas, berikut ini disajikan rincian jenis dan frekuensi keseluruhan data kesalahan tersebut.

Tabel 4.2 Jenis dan Frekuensi Kesalahan EYD

\begin{tabular}{|c|l|c|}
\hline No. & \multicolumn{1}{|c|}{ Jenis Kesalahan EYD } & Frekuensi Kesalahan \\
\hline 1. & kesalahan pemakaian huruf kapital & 30 \\
\hline 2. & kesalahan pemakaiaan huruf tebal & 4 \\
\hline 3. & kesalahan penulisan kata turunan & 2 \\
\hline 4. & kesalahan penulisan gabungan kata & 1 \\
\hline 5. & kesalahan penulisan kata depan & 11 \\
\hline 6. & kesalahan penulisan singkatan & 5 \\
\hline 7. & kesalahan pemakaian tanda titik (.) & 16 \\
\hline 8. & kesalahan pemakaian tanda koma (,) & 71 \\
\hline 9. & kesalahan pemakaian tanda titik dua (:) & Jumlah \\
\hline & &
\end{tabular}

Tabel 4.3 Jenis dan Frekuensi Kesalahan Diksi

\begin{tabular}{|c|l|c|}
\hline No. & \multicolumn{1}{|c|}{ Jenis Kesalahan Diksi } & $\begin{array}{c}\text { Frekuensi } \\
\text { Kesalahan }\end{array}$ \\
\hline 1. & $\begin{array}{l}\text { kata-kata yang digunakan adalah kata-kata yang tidak baku } \\
\text { 2. }\end{array}$ & $\begin{array}{l}\text { kata-kata yang dipilih tidak mengungkapkan pengertian } \\
\text { yang tepat }\end{array}$ \\
\hline 3. & $\begin{array}{l}\text { kata dan pembentukannya tidak sesuai dengan kaidah bahasa } \\
\text { yang bersangkutan }\end{array}$ & 2 \\
\hline 4. & $\begin{array}{l}\text { kata atau kelompok kata yang digunakan tidak sesuai dengan } \\
\text { maksud yang diinginkan }\end{array}$ & 30 \\
\hline & \multicolumn{1}{|c}{ Jumlah } \\
\hline
\end{tabular}


Tabel 4.4 Jenis dan Frekuensi Kesalahan Kalimat

\begin{tabular}{|c|c|c|}
\hline No. & Jenis Kesalahan Kalimat & Frekuensi Kesalahan \\
\hline 1. & Subjek Berpreposisi & 1 \\
\hline 2. & Pemakaian Preposisi yang Tidak Tepat & 1 \\
\hline 3. & $\begin{array}{l}\text { Penggunaan Kata yang Mempunyai Kemiripan } \\
\text { Makna atau Fungsi Secara Berganda }\end{array}$ & 2 \\
\hline 4. & Penghilangan Konjungsi & 1 \\
\hline 5. & Penggunaan Konjungsi yang Tidak Tepat & 3 \\
\hline 6. & Susunan Kata yang Tidak Tepat & 2 \\
\hline 7. & Penggunaan Unsur yang Berlebihan atau Mubazir & 6 \\
\hline 8. & Kalimat Tidak Berpredikat & 4 \\
\hline 9. & $\begin{array}{l}\text { Kalimat Tidak Bersubjek dan Tidak Berpredikat } \\
\text { (Kalimat Buntung) }\end{array}$ & 1 \\
\hline & Jumlah & 21 \\
\hline
\end{tabular}

Tabel 4.5 Jenis dan Frekuensi Kesalahan Paragraf

\begin{tabular}{|c|l|c|}
\hline No. & \multicolumn{1}{|c|}{ Jenis Kesalahan Paragraf } & Frekuensi Kesalahan \\
\hline 1. & Ketidaksatuan & 6 \\
\hline 2. & Kelengkapan Jumlah & 1 \\
\hline \multicolumn{2}{|r|}{ Jum } \\
\hline
\end{tabular}

Tabel 4.6 Jenis dan Frekuensi Kesalahan Sistematika Penulisan Kata Pengantar

\begin{tabular}{|c|l|c|}
\hline No. & \multicolumn{1}{|c|}{ Jenis Kesalahan Sistematika Penulisan Kata Pengantar } & $\begin{array}{c}\text { Frekuensi } \\
\text { Kesalahan }\end{array}$ \\
\hline 1. & $\begin{array}{l}\text { tajuk kata pengantar tidak menggunakan huruf Times New } \\
\text { Roman } 12 \mathrm{pt} \text { atau Garamond } 13 \mathrm{pt}\end{array}$ & 1 \\
\hline 2. & tajuk kata pengantar dicetak menggunakan huruf tebal & 4 \\
\hline 3. & $\begin{array}{l}\text { awal paragraf kata pengantar tidak dimulai 1,2 cm dari tepi kiri } \\
\text { bidang pengetikan }\end{array}$ & 1 \\
\hline 4. & isi kata pengantar tidak diketik dengan jarak dua spaci & 1 \\
\hline
\end{tabular}




\begin{tabular}{|c|l|c|}
\hline 5. & $\begin{array}{l}\text { ucapan terima kasih penulis yang pertama tidak ditujukan } \\
\text { kepada dosen pembimbing }\end{array}$ & 2 \\
\hline 6. & $\begin{array}{l}\text { cara penulisan atau tata letak nama kota (tempat), tanggal, } \\
\text { bulan (ditulis lengkap dengan huruf, bukan angka), dan tahun } \\
\text { penyusunan karya ilmiah }\end{array}$ & 2 \\
\hline 7. & nomor halaman kata pengantar yang tidak dicantumkan & 15 \\
\hline \multicolumn{2}{|l}{ Jumlah } & \\
\hline
\end{tabular}

Dengan demikian, frekuensi relatif (angka persenan) kelima aspek data kesalahan di atas dapat ditentukan dengan rumus yang dikemukakan oleh Sudijono (2009:43) berikut ini.

$$
\mathrm{P}=\frac{\mathrm{f}}{\mathrm{N}} \times 100 \%
$$

$\mathrm{P} \quad=$ angka persentase yang dicari

$\mathrm{f} \quad=$ frekuensi banyaknya kesalahan EYD, diksi, kalimat, paragraf, dan sistematika penulisan kata pengantar

$\mathrm{N}=$ Number of Cases (jumlah keseluruhan kesalahan penggunaan bahasa Indonesia dalam kata pengantar)

$100=$ bilangan tetap

Sesuai rumus di atas, hasil persentase kelima aspek data kesalahan tersebut adalah (1) kesalahan EYD 50\%, (2) kesalahan diksi 21\%, (3) kesalahan kalimat sebanyak 15\%, (4) kesalahan paragraf 5\%, dan (5) kesalahan sistematika penulisan kata pengantar $11 \%$. Jadi, kesalahan penggunaan bahasa Indonesia yang dominan muncul adalah aspek kesalahan ejaan atau EYD.

\section{PENUTUP}

Setelah mengumpulkan, mengklasifikasikan, dan menganalisis data maka dapat disimpulkan beberapa hal berikut ini.

Pertama, kesalahan penggunaan bahasa Indonesia pada kata pengantar mahasiswa PBSI FKIP Unsyiah tahun 2010 adalah sebagai berikut: 
1) kesalahan aspek EYD, antara lain, (a) pemakaian huruf (huruf kapital dan huruf tebal), (b) penulisan kata turunan, (c) penulisan gabungan kata, (d) penulisan kata depan, (e) penulisan singkatan, dan (f) pemakaian tanda baca (tanda titik [.], tanda koma [,], dan tanda titik dua [:]);

2) kesalahan aspek diksi (pilihan kata), antara lain, (a) kata-kata yang digunakan adalah kata-kata yang tidak baku, (b) kata-kata yang dipilih tidak mengungkapkan pengertian yang tepat, (c) kata dan pembentukannya tidak sesuai dengan kaidah bahasa yang bersangkutan, dan (d) kata atau kelompok kata yang digunakan tidak sesuai dengan maksud yang diinginkan;

3) kesalahan aspek kalimat, antara lain, (a) subjek berpreposisi, (b) pemakaian preposisi yang tidak tepat, (c) penggunaan kata yang mempunyai kemiripan makna atau fungsi secara berganda, (d) penghilangan konjungsi, (e) penggunaan konjungsi yang tidak tepat, (f) susunan kata yang tidak tepat, (g) penggunaan unsur yang berlebihan atau mubazir, (h) kalimat tidak berpredikat, dan (i) kalimat tidak bersubjek dan tidak berpredikat (kalimat buntung);

4) kesalahan aspek paragraf karena tidak memenuhi syarat-syarat paragraf yang baik, yaitu (a) keruntutan atau kesatuan dan (b) kelengkapan;

5) kesalahan sistematika penulisan kata pengantar, antara lain, (a) tajuk kata pengantar tidak menggunakan huruf Times New Roman 12 pt atau Garamond 13 pt, (b) tajuk kata pengantar dicetak menggunakan huruf tebal, (c) awal paragraf kata pengantar dimulai $1,2 \mathrm{~cm}$ dari tepi kiri bidang pengetikan, (d) isi kata pengantar tidak diketik dengan jarak 2 spaci, (e) ucapan terima kasih penulis yang pertama tidak ditujukan kepada dosen pembimbing, (f) cara penulisan atau tata letak nama kota (tempat), tanggal, bulan (ditulis lengkap dengan huruf, bukan angka), dan tahun penyusunan karya ilmiah, dan (g) nomor halaman kata pengantar tidak dicantumkan.

Kedua, berdasarkan analisis yang telah dilakukan dalam kata pengantar mahasiswa PBSI FKIP Unsyiah tahun 2010, hasil persentase kelima aspek data kesalahan tersebut adalah (1) kesalahan EYD 50\%, (2) kesalahan diksi 21\%, (3) kesalahan kalimat sebanyak 15\%, (4) kesalahan paragraf 5\%, dan (5) kesalahan 
sistematika penulisan kata pengantar $11 \%$. Jadi, kesalahan penggunaan bahasa Indonesia yang dominan muncul adalah aspek kesalahan ejaan atau EYD.

Berdasarkan hasil penelitian di atas, saran penulis adalah sebagai berikut. Pertama, bagi semua mahasiswa yang berkecimpung dalam bidang ilmu bahasa dan sastra Indonesia, khususnya mahasiswa PBSI FKIP Unsyiah harus lebih meningkatkan pengetahuannya tentang penggunaan bahasa Indonesia yang baik dan benar dalam penulisan karya ilmiah, terutama pedoman Ejaan Yang Disempurnakan (EYD) dan bahasa baku. Jika bahasa tulis yang disampaikan baik dan benar, pembaca akan lebih mudah memahami maksud penulis. Kedua, bagi semua dosen pembimbing skripsi atau pendidik hendaknya lebih memperhatikan dan membimbing mahasiswanya supaya tidak melakukan kesalahan penggunaan bahasa Indonesia dalam menulis karya ilmiah, salah satunya kata pengantar skripsi.

\section{DAFTAR PUSTAKA}

Arifin, Zaenal dan Farid Hadi. 2001. Seribu Satu Kesalahan Berbahasa. Jakarta: Akademika Pressindo.

Arikunto, Suharsimi. 2006. Prosedur Penelitian Suatu Pendekatan Praktik. Jakarta: Rineka Cipta.

Azwardi. 2009. "Menulis Ilmiah Mata Kuliah Bahasa Indonesia Umum untuk Mahasiswa”. Banda Aceh: Universitas Syiah Kuala.

Basrowi dan Suwandi. 2008. Memahami Penelitian Kualitatif. Jakarta: Rineka Cipta.

Chaer, Abdul. 2006. Tata Bahasa Praktis Bahasa Indonesia (Edisi Revisi). Jakarta: Rineka Cipta.

--------. 2007. Linguistik Umum. Jakarta: Rineka Cipta.

Danim, Sudarwan. 2002. Menjadi Peneliti Kualitatif. Jakarta: Pustaka Setia.

Departemen Pendidikan Nasional. 2008. Kamus Besar Bahasa Indonesia Pusat Bahasa Edisi Keempat. Jakarta: PT Gramedia Pustaka Utama.

Djiwandono, M. Soenardi. 2008. Tes Bahasa Pegangan bagi Pengajar Bahasa. Jakarta: Indeks. 
Fakultas Keguruan dan Ilmu Pendidikan. 2007. Pedoman Penulisan Skripsi. Banda Aceh.

Hastuti, Sri. 1989. Sekitar Analisis Kesalahan Berbahasa Indonesia. Yogyakarta: Mitra Gama Widya.

Kridalaksana, Harimurti. 2001. Kamus Linguistik (Edisi Ketiga). Jakarta: Gramedia Pustaka Utama.

Kosasih, E. 2003. Ketatabahasaan dan Kesusastraan. Bandung: Yrama Widya.

Mustakim. 1992. Tanya Jawab Ejaan Bahasa Indonesia untuk Umum. Jakarta: Gramedia Pustaka Utama.

-------. 1994. Membina Kemampuan Berbahasa. Jakarta: Gramedia.

Ningsih, Erni. 2010. "Analisis Kesalahan Penggunaan Ejaan pada Skripsi Mahasiswa Nonbahasa Indonesia FKIP Unsyiah”. Skripsi Tidak Diterbitkan. Banda Aceh: FKIP Unsyiah.

Parwanto, dkk. 2006. Prosedur Penelitian dengan Pendekatan Praktek. Jakarta: Badan Penelitian dan Pengembangan Departemen Pendidikan Nasional.

Permendiknas. 2010. Ejaan Bahasa Indonesia yang Disempurnakan. Yogyakarta: Pustaka Timur.

Setyawati, Nanik. 2010. Analisis Kesalahan Berbahasa Indonesia. Surakarta: Yusma Pustaka.

Sudijono, Anas. 2009. Pengantar Statistik Pendidikan. Jakarta: Raja Grafindo Persada.

Sugono, Dendy. 1999. Berbahasa Indonesia yang Benar. Jakarta: Puspa Swara.

Suryaman, Ukun. 1998. Dasar-Dasar Bahasa Indonesia Baku. Bandung: Alumni.

Taib, Rostina. 2008. “Sintaksis”. Banda Aceh: Universitas Syiah Kuala.

Tarigan, Hendry Guntur. 1994. Menulis Sebagai Keterampilan Berbahasa. Bandung: Angkasa.

---------. 1995. Pengajaran Analisis Kesalahan Bahasa Indonesia. Bandung: Angkasa.

Tim Balai Bahasa Provinsi Jawa Tengah. 2008. Pedoman Penulisan Karya Ilmiah. Semarang: Balai Bahasa Provinsi Jawa Tengah. 
Umar, Husein. 2005. Metode Penelitian untuk Skripsi dan Tesis Bisnis. Jakarta: Raja Grafindo Persada.

Widjono, Hs. 2007. Bahasa Indonesia Mata Kuliah Pengembangan Kepribadian di Perguruan Tinggi. Jakarta: PT. Gramedia Widiasarana Indonesia.

Wiyanto, Asul. 2004. Terampil Menulis Paragraf. Jakarta: PT Gramedia Widiasarana Indonesia. 